\title{
EFEK VARIASI CAMPURAN BAHAN BAKAR DIESEL, METANOL KADAR RENDAH DAN JATROPHA TERHADAP EQUIVALENCE RATIO PADA MESIN DIESEL DENGAN HOT EGR
}

\author{
YAFID EFFENDI \\ Program Studi Teknik Mesin, Fakultas Teknik, Universitas Muhammadiyah Tangerang \\ Jl. Perintis Kemerdekaan I/33 Cikokol-Tangerang \\ Email: yafid_effendi@yahoo.com
}

\begin{abstract}
ABSTRAK
Salah satu jenis mesin kendaraan bermotor yang sangat sesuai untuk transportasi dan kendaraan alat berat adalah mesin diesel, karena efisiensi pembakaran yang tinggi, kehandalan, fleksibilitas bahan bakar, dan rendahnya konsumsi bahan bakar membuat diesel banyak digunakan di beberapa Negara. Campuran metanol kadar rendah dan jatropha digunakan sebagai bahan bakar alternatif. Pengujian ini dilakukan dengan menggunakan variasi prosentase beban, yaitu pada beban $25 \%, 50 \%, 75 \%$, dan $100 \%$ dengan variasi bahan bakar diesel murni (D100) dan campuran bahan bakar biosolar, metanol kadar rendah dan jatropha (D85LPM5J10, D80LPM10J10, D75LPM15J10, D75LPM5J20, D70LPM10J20, D65LPM15J20, D65LPM5J30, D60LPM10J30 dan D55LPM15J30) pada $2000 \mathrm{rpm}$. Hal ini bertujuan untuk mengetahui seberapa besar equivalence ratio yang dihasilkan ketika tanpa katub (OEV) dibandingkan dengan ketika katub (OEV) dan ketika menggunakan bahan bakar diesel murni dibandingkan dengan ketika menggunakan campuran bahan bakar biosolar, metanol kadar rendah dan jatropha pada mesin diesel Isuzu 4JB1 injeksi langsung dengan sistem Hot EGR (Exhaust Gas Recirculation). Metanol kadar rendah yang digunakan mempunyai kadar air $24,88 \%$ berbasis volume. Penelitian ini dilakukan eksperimen dilaboratorium thermofluid UNDIP. Hasil penelitian ini, dengan meningkatkan nilai equivalence ratio diikuti peningkatan EGR. Nilai equivalence ratio cenderung menurun ketika menggunakan campuran bahan bakar dibandingkan D100. Ada beberapa campuran bahan bakar terjadi peningkatan nilai equivalence ratio dibandingkan D100 untuk D65LPM15J20 dan D80LPM10J10 pada beban rendah (25\%) sebesar 4.52\% dan $11.4 \%$.
\end{abstract}

Kata Kunci: Rasio Ekuivalen, EGR, Biosolar, Metanol, Jatropha

\section{PENDAHULUAN}

Bertambahnya jumlah kendaraan bermotor dan krisis bahan bakar dianggap berdampak buruk pada lingkungan. Telah terbukti bahwa polutan dari emisi kendaraan bermotor berdampak signifikan terhadap sistem ekologi dan kesehatan manusia (Lei Zhu et all, 2010). Salah satu jenis mesin kendaraan bermotor yang sangat sesuai untuk transportasi dan kendaraan alat berat adalah mesin diesel. Kontribusinya untuk kesejahteraan ekonomi, efisiensi pembakaran yang tinggi, kehandalan, fleksibilitas bahan bakar, dan rendahnya konsumsi bahan bakar membuat diesel banyak digunakan di beberapa negara (Zhiqiang Guo et all, 2011). Meskipun memiliki beberapa keuntungan tersebut, mesin diesel memiliki masalah tentang pencemaran udara yang ditandai dengan adanya asap hitam atau gas buang sisa hasil pemakaran. $\mathrm{NO}_{\mathrm{x}}$ dan $\mathrm{PM}$ (particular matter) merupakan emisi paling tinggi yang dikeluarkan dari hasil sisa pembakaran mesin diesel dibandingkan HC (hydrocarbon) dan 
CO (carbonmonoksida) (Asif Faiz, et all., 1996).

Bahan bakar diesel merupakan bahan bakar fosil yang tidak dapat diperbaharui karena terbentuknya membutuhkan waktu berjuta-juta tahun lamanya. Biodiesel merupakan bahan bakar alternatif pengganti bahan bakar diesel (Lei Zhu et all, 2010). Beberapa keuntungan jatropha dapat langsung digunakan pada mesin diesel, dapat dicampur dengan metanol, mempunyai cetane number yang tinggi dan calorific value, serta merupakan sumber energi yang dapat diperbaharui (renewable fuels), dan juga tidak termasuk kategori minyak pangan (non-edible). Kekurangannya mempunyai viskositas yang tinggi serta volatility rendah sehingga sulitnya atom bahan bakar bercampurnya dengan udara dan tingginya emisi smoke, $\mathrm{HC}$ dan CO (M. Senthil Kumar et all., 2003). Sedangkan keuntungan metanol diantaranya, rendah viskositas sehingga dapat dengan mudah diinjeksikan, dikabutkan dan dicampur dengan udara, rendah emisi karena tingginya rasio stokiometri udara dan bahan bakar, serta dapat meningkatkan efisiensi termal mesin (Cenk Sayin et all., 2010). Metanol digunakan juga sebagai aditif campuran bahan bakar yang menyediakan oksigen dan meningkatkan panas penguapan serta berpotensi mereduksi jumlah $\mathrm{NO}_{\mathrm{x}}$ dan PM (Particular Matter) (Lei Zhu, et all, 2010).

Salah satu cara untuk mereduksi tingginya emisi $\mathrm{NO}_{\mathrm{x}}$ yang ditimbulkan mesin diesel dan mengurangi konsumsi bahan bakar digunakan metode EGR (Exhaust Gas Recirculation) (Vinod SinghYadav, et all., 2012). Metode ini dilakukan dengan mensirkulasikan sebagian gas buang ke dalam intake manifold yang kemudian bercampur dengan udara sebelum masuk ke dalam ruang bakar.

Laju aliran massa bahan bakar $\left(\dot{\mathrm{m}}_{f}\right)$, dan laju aliran massa udara $\left(\dot{\mathrm{m}}_{a}\right)$ dapat diukur pada pengujian mesin. Perbandingan antara keduanya berguna untuk mengetahui kondisi operasi mesin:

$$
\begin{aligned}
& \text { Air/fuel ratio (A/F) }=\frac{\dot{m}_{a}}{\dot{m}_{f}} \\
& \text { Fuel/air ratio }(\mathrm{F} / \mathrm{A})=\frac{\dot{m}_{f}}{\dot{m}_{a}} .
\end{aligned}
$$

Rasio ekuivalen merupakan parameter yang berguna untuk menentukan komposisi campuran udara-bahan bakar yang baik karena rasio stokiometri udara/bahan bakar bergantung pada komposisi bahan bakar dan komposisi produk pembakaran yang secara signifikan berbeda untuk campuran bahan bakar miskin dan bahan bakar kaya. Rasio ekuivalen udara/bahan bakar $(\phi)$ :

$\phi=\frac{(F / A)_{\text {aktual }}}{(F / A)_{s}}$

Jika $\phi>1$ maka campuran itu kaya akan bahan bakar, $\phi=1$ campuran stokiometri dan $\phi<1$ maka campuran itu miskin akan bahan bakar

Kisaran rasio udara/bahan bakar dengan bahan bakar/udara pada pengoperasian normal untuk mesin dengan bahan bakar diesel yaitu $18 \leq \mathrm{A} / \mathrm{F} \leq 70(0,014 \leq \mathrm{F} / \mathrm{A} \leq$ $0,056)$. Jika oksigen yang dibutuhkan tercukupi, bahan bakar hidrokarbon dapat dioksidasi sempurna. Karbon (C) pada bahan bakar kemudian berubah menjadi karbon dioksida $\left(\mathrm{CO}_{2}\right)$ dan untuk hidrogen $(\mathrm{H})$ berubah menjadi uap air $\left(\mathrm{H}_{2} \mathrm{O}\right)$. Jika jumlah udara yang diberikan kurang dari yang dibutuhkan secara stokiometri maka akan terjadi campuran kaya bahan bakar. Produk dari campuran kaya bahan bakar adalah $\mathrm{CO}$, $\mathrm{CO}_{2}, \mathrm{H}_{2} \mathrm{O}$ dan $\mathrm{HC}$ (hidrokarbon tidak terbakar). Jika jumlah udara yang diberikan lebih besar dari kebutuhan maka akan terjadi campuran miskin bahan bakar [Heywood, 1988].

Berdasarkan pendahuluan diatas, maka peneliti mengadakan eksperimen tentang penggunaan campuran biosolar, LPM dan jatropha. Pada penelitian ini, peneliti memfokuskan untuk mengetahui pengaruh metanol kadar rendah (Low Purity Methanol/LPM) saat dipakai sebagai campuran biosolar dan jatropha terhadap rasio ekuivalen mesin diesel.

\section{METODOLOGI PENELITIAN}

Pengujian ini dilakukan eksperimen dilaboratorium thermofluid UNDIP dengan menggunakan variasi prosentase beban, yaitu pada beban $25 \%, 50 \%$, 75\%, dan $100 \%$ dengan variasi bahan bakar diesel murni (D100) dan campuran bahan bakar biosolar, metanol kadar rendah dan jatropha (D85LPM5J10, D80LPM10J10，D75LPM1 
5J10, D75LPM5J20, D70LPM10J20, D65LP M15J20, D65LPM5J30, D60LPM10J30 dan D55LPM15J30) pada $2000 \mathrm{rpm}$. Penelitian ini menggunakan mesin diesel 4 silinder, 4 langkah DI dengan skema alat dan spesifikasi mesin sebagai berikut:

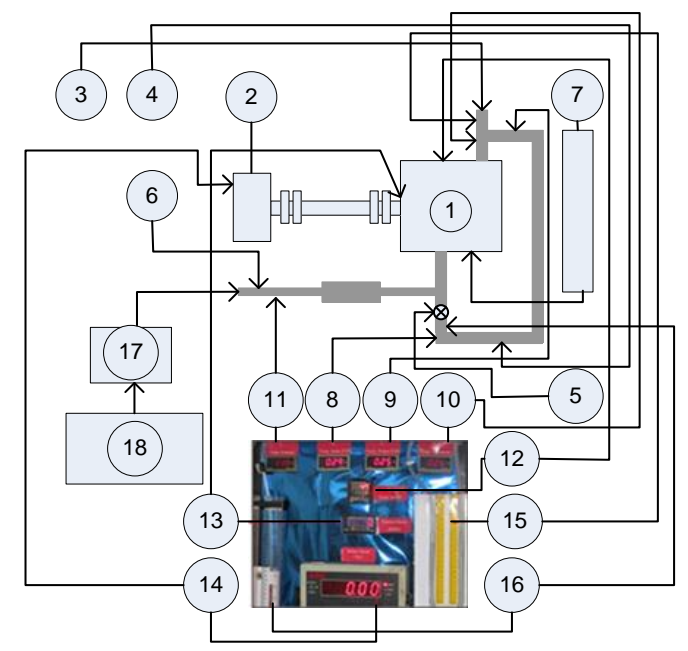

Gambar 1. Deskripsi alat uji

1. Keterangan:

2. Mesin diesel

3. Dynamometer

4. Intake manifold

5. Exhaust gas recirculation

6. Katub bukaan $E G R$

7. Exhaust gas

8. Buret

9. Temperatur input EGR

10. Temperatur output EGR

11. Temperatur campuran

12. Temperatur Exhaust gas

13. Temperatur mesin

14. Putaran mesin

15. Beban

16. Manometer udara

17. Manometer $E G R$

18. Smoke meter

19. Opacity

Tabel 1 Spesifikasi Mesin

\begin{tabular}{|l|l|}
\hline \multicolumn{1}{|c|}{ Spesifikasi } & \multicolumn{2}{c|}{ Uraian } \\
\hline Type Motor & Diesel, OHV, vertical in line, Direct Injection, 4JB1 \\
\hline Jumlah silinder & 4 silinder \\
\hline Diameter langkah & $93 \mathrm{~mm} \times 102 \mathrm{~mm}$ \\
\hline Volume silinder & $2771 \mathrm{cc}$ \\
\hline Daya maksimum & $70 / 3000(\mathrm{HP} / \mathrm{rpm})$ \\
\hline Torsi maksimum & $132 / 2000(\mathrm{lb} . \mathrm{ft} / \mathrm{rpm})$ \\
\hline Rasio kompresi & $18,2: 1$ \\
\hline
\end{tabular}

Tabel 2. Spesifikasi Bahan Bakar

\begin{tabular}{|c|l|c|c|c|}
\hline No. & \multicolumn{1}{|c|}{ Parameter Uji } & $\begin{array}{c}\text { Solar } \\
\text { (EURO II) }\end{array}$ & $\begin{array}{c}\text { Metanol Kadar } \\
\text { Rendah } \\
\text { (Low Purity } \\
\text { Methanol) }\end{array}$ & $\begin{array}{c}\text { Jatropha } \\
\text { (minyak } \\
\text { jarak) }\end{array}$ \\
\hline 1 & Viskositas $\left(40^{\circ} \mathrm{C}\right.$ ) cP & $2-5$ & 0,46 & 3,23 \\
\hline 2 & Nilai Kalor $(\mathrm{J} / \mathrm{gr})$ & 45213,80 & 21730 & 37968 \\
\hline 3 & Angka Cetana & 48 & 3,3 & 41,8 \\
\hline 4 & Flash Point ${ }^{\circ} \mathrm{C}$ & 60 & 10,7 & 198 \\
\hline 5 & Water Content (\% v) & 0,05 & 24,88 & 3,16 \\
\hline
\end{tabular}

\section{HASIL DAN PEMBAHASAN}

a. Pengaruh EGR Terhadap Equivalence Ratio.

Pengujian ini dilakukan untuk mengetahui Pengaruh EGR terhadap equivalence ratio dengan katub OEV $0 \%, 25 \%, 50 \%$, $75 \%$ dan $100 \%$. Membandingkan katub (OEV) dengan tanpa katub (OEV) terhadap equivalence ratio untuk memperoleh nilai perubahan maksimumnya. Untuk memperoleh nilai equivalence ratio maksimal, dilakukan dengan cara membandingkan equivalence ratio yang dihasilkan dari masingmasing katub OEV. Hasil pengujian Pengaruh EGR terhadap equivalence ratio ditunjukkan pada Gambar 2 s/d Gambar 11.

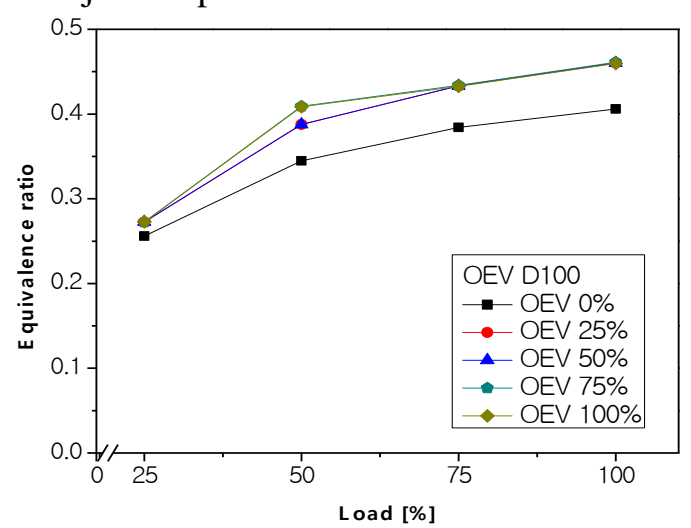

Gambar 2. Pengaruh EGR terhadap equivalence ratio dengan variasi beban menggunakan bahan bakar D100.

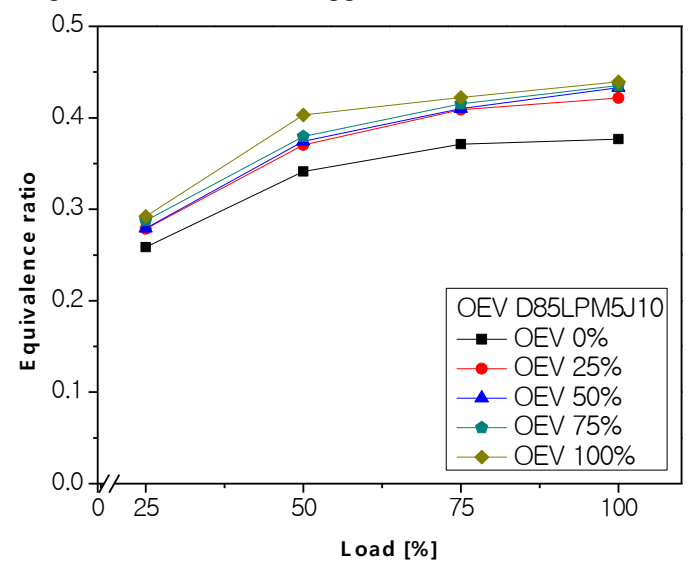

Gambar 3. Pengaruh EGR terhadap equivalence ratio dengan variasi beban menggunakan bahan bakar D85LPM5J10. 


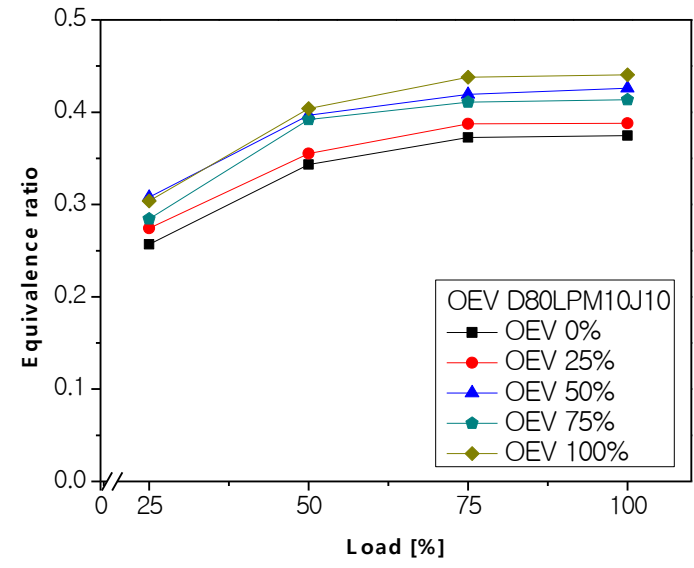

Gambar 4. Pengaruh EGR terhadap equivalence ratio dengan variasi beban menggunakan bahan bakar D80LPM10J10.

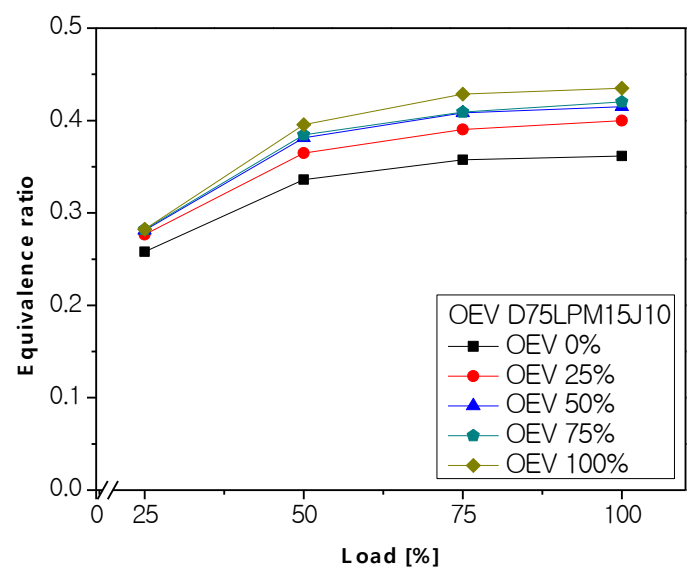

Gambar 5 Pengaruh EGR terhadap equivalence ratio dengan variasi beban menggunakan bahan bakar D75LPM15J10.

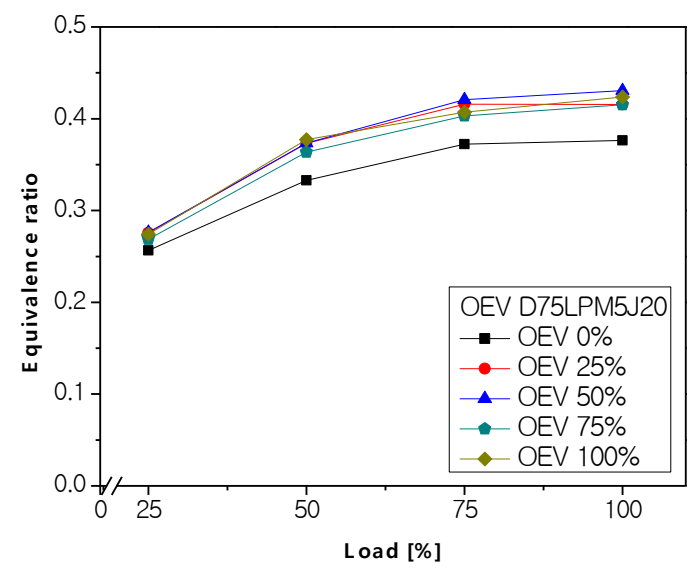

Gambar 6 Pengaruh EGR terhadap equivalence ratio dengan variasi beban menggunakan bahan bakar D75LPM5J20.

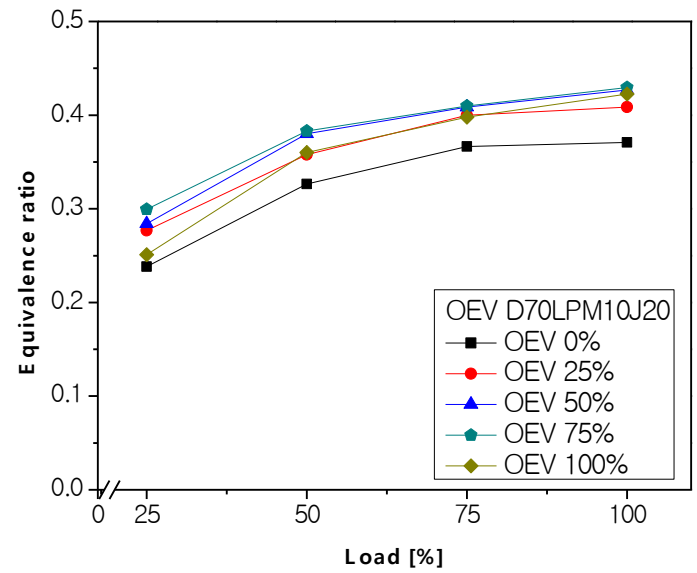

Gambar 7 Pengaruh EGR terhadap equivalence ratio dengan variasi beban menggunakan bahan bakar D70LPM10J20.

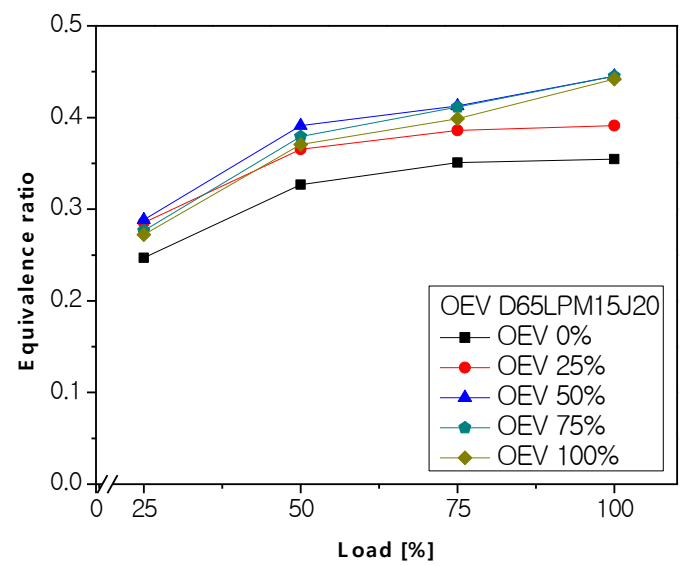

Gambar 8 Pengaruh EGR terhadap equivalence ratio dengan variasi beban menggunakan bahan bakar D65LPM15J20.

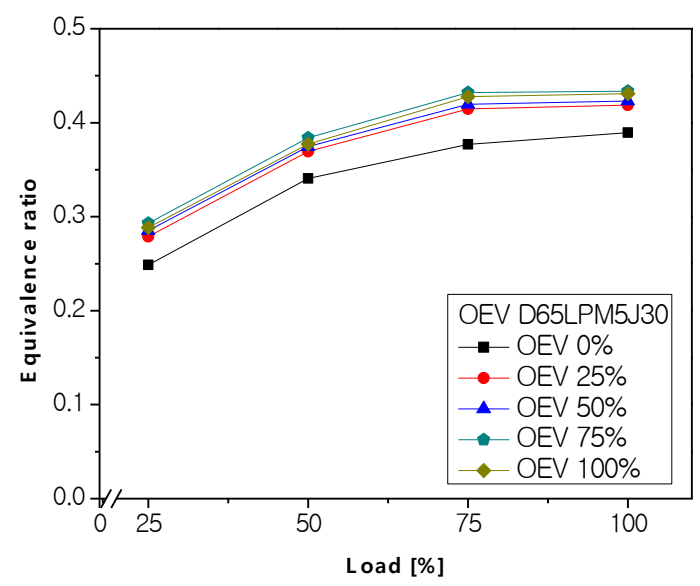

Gambar 9 Pengaruh EGR terhadap equivalence ratio dengan variasi beban menggunakan bahan bakar D65LPM5J30. 


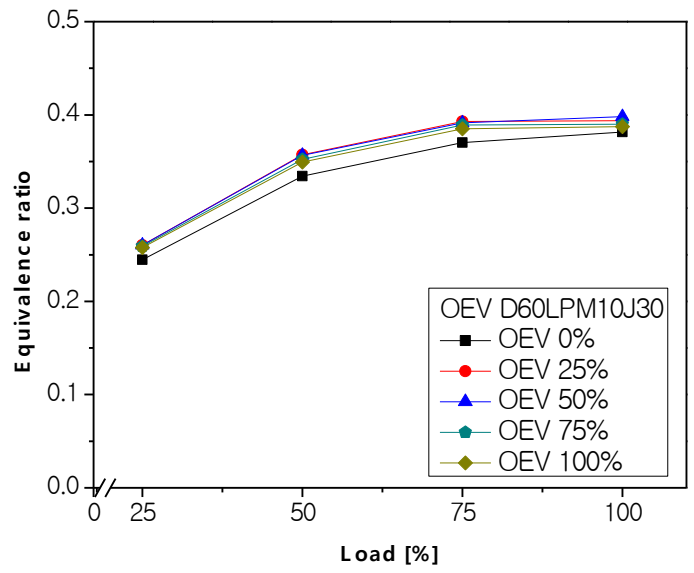

Gambar 10 Pengaruh EGR terhadap equivalence ratio dengan variasi beban menggunakan bahan bakar D60LPM10J30.

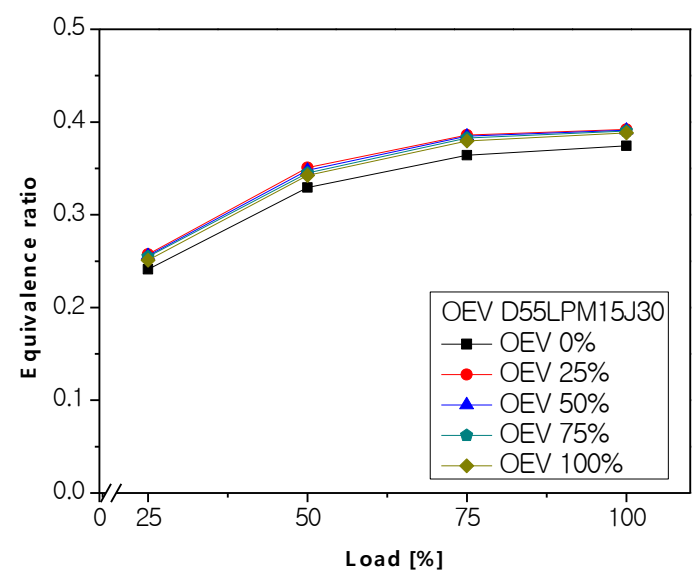

Gambar 11. Pengaruh EGR terhadap equivalence ratio dengan variasi beban menggunakan bahan bakar D55LPM15J30.

Gambar 2 s/d Gambar 11 menunjukkan nilai equivalence ratio meningkat dengan meningkatnya beban. Nilai equivalence ratio meningkat ketika menggunakan EGR dikarenakan berkurangnya jumlah udara segar di dalam ruang bakar akibat dari sebagian gas buang yang disirkulasikan ke dalam ruang bakar sehingga mengurangi jumlah oksigen yang diperlukan di dalam ruang bakar [Agarwal et all., 2011].

Pada Gambar 2 untuk bahan bakar D100 dengan penambahan EGR equivalence ratio cenderung naik. Nilai equivalence ratio tertinggi terjadi pada katub (OEV) $75 \%$. Kenaikan nilai equivalence ratio katub (OEV) $75 \%$ pada beban $100 \%$ sebesar $11.92 \%$ dibandingkan dengan tanpa EGR.

Begitupun dengan penambahan jatropha $10 \%$, nilai equivalence ratio meningkat ketika menggunakan EGR dibandingkan tanpa
EGR. Pada bahan bakar D85LPM5J10 Gambar 3 nilai equivalence ratio tertinggi terjadi pada katub (OEV) $100 \%$ pada beban $100 \%$ sebesar $14.28 \%$. Demikian pula Gambar 4 untuk bahan bakar D80LPM10J10 dengan penambahan EGR equivalence ratio cenderung meningkat. Nilai equivalence ratio tertinggi terjadi pada katub (OEV) $100 \%$ pada beban $100 \%$ sebesar $14.91 \%$ dibandingkan tanpa EGR. Sama halnya untuk bahan bakar D75LPM15J10 tampak Gambar 5 dengan penggunaan EGR equivalence ratio cenderung naik dibandingkan tanpa EGR. Nilai equivalence ratio tertinggi terjadi pada katub (OEV) $100 \%$ pada beban $100 \%$ sebesar $16.9 \%$.

Demikian juga dengan penambahan jatropha 20\%, ketika penggunaan EGR nilai equivalence ratio cenderung meningkat dibandingkan tanpa EGR untuk bahan bakar D75LPM5J20 terlihat pada Gambar 6. Nilai equivalence ratio tertinggi terjadi pada katub (OEV) $50 \%$ pada beban $100 \%$ sebesar $12.56 \%$. Sama juga Gambar 7 untuk bahan bakar D70LPM10J20 dengan penambahan EGR equivalence ratio cenderung naik. Nilai equivalence ratio tertinggi terjadi pada katub (OEV) $75 \%$ pada beban $100 \%$ sebesar $13.66 \%$, dan juga Gambar 8 untuk bahan bakar D65LPM15J20 dengan penambahan EGR equivalence ratio meningkat juga. Nilai equivalence ratio tertinggi terjadi pada katub (OEV) $75 \%$. Kenaikan nilai equivalence ratio katub (OEV) $75 \%$ dibandingkan tanpa EGR pada beban $100 \%$ sebesar $20.36 \%$.

Sama halnya jatropha $30 \%$ nilai equivalence ratio meningkat ketika menggunakan EGR dibandingkan tanpa EGR. Tampak pada Gambar 9 untuk bahan bakar D65LPM5J30 nilai equivalence ratio tertinggi terjadi pada katub (OEV) $75 \%$ pada beban penuh sebesar $10.19 \%$. Seperti juga bahan bakar D60LPM10J30 Gambar 10 nilai equivalence ratio tertinggi terjadi pada katub (OEV) 50\% untuk beban penuh sebesar $4.19 \%$, begitupun bahan bakar D55LPM $15 J 30$ terlihat pada Gambar 11 nilai equivalence ratio tertinggi terjadi pada beban penuh katub (OEV) 25\% sebesar $4.55 \%$.

\section{b. Pengaruh Variasi Campuran Bahan Bakar Terhadap Equivalence Ratio}

Pengujian ini dilakukan untuk menge- 
tahui pengaruh bahan bakar terhadap equivalence ratio dengan variasi campuran bahan bakar yaitu D85LPM5J10, D80LPM10J10, D75LPM15J10, D75LPM5J20, D70LPM 10J20，D65LPM15J20，D65LPM5J30，D60 LPM10J30 dan D55LPM15J30. Hasil pengujian dari masing-masing bahan bakar tersebut dibandingkan dengan D100 untuk mendapatkan nilai maksimum dan minimum dari perubahan equivalence ratio. Sedangkan untuk memperoleh nilai equivalence ratio maksimum, didapatkan dengan membandingkan nilai equivalence ratio yang dihasilkan dari masing-masing bahan bakar. Hasil pengujian pengaruh bahan bakar terhadap equivalence ratio ditunjukkan pada Gambar 12 s/d Gambar 16.

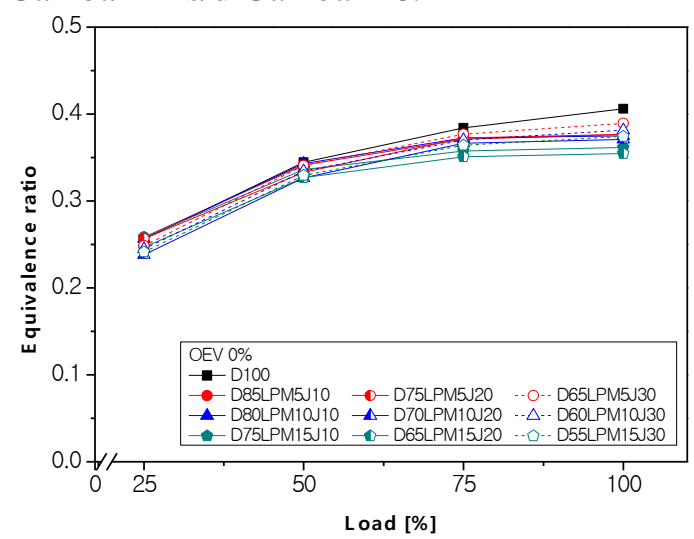

Gambar 12 Pengaruh campuran bahan bakar terhadap equivalence ratio dengan variasi beban menggunakan bukaan katub (OEV) $0 \%$.

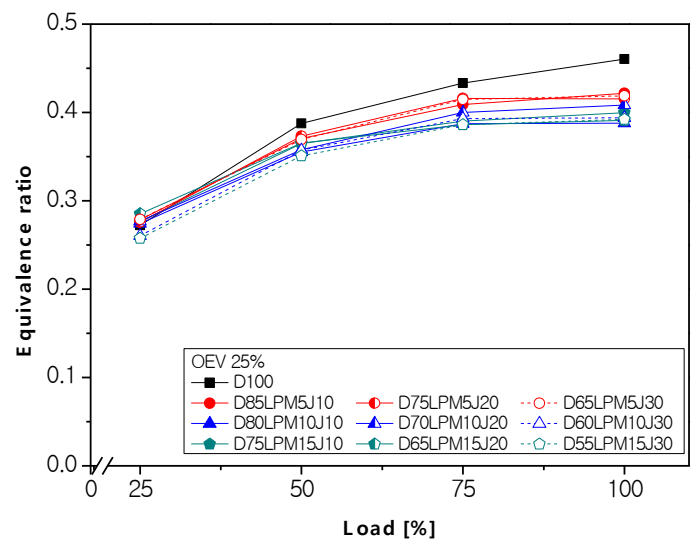

Gambar 13 Pengaruh campuran bahan bakar terhadap equivalence ratio dengan variasi beban menggunakan bukaan katub (OEV) $25 \%$.

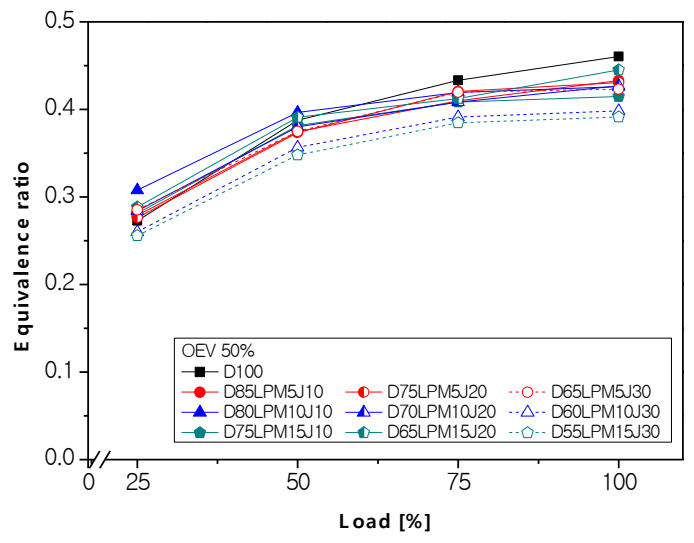

Gambar 14 Pengaruh campuran bahan bakar terhadap equivalence ratio dengan variasi beban menggunakan bukaan katub (OEV) $50 \%$.

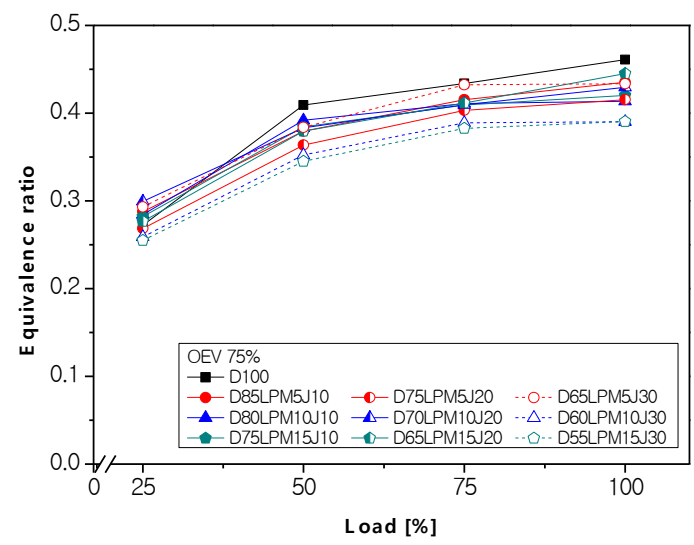

Gambar 15 Pengaruh campuran bahan bakar terhadap equivalence ratio dengan variasi beban menggunakan bukaan katub (OEV) $75 \%$.

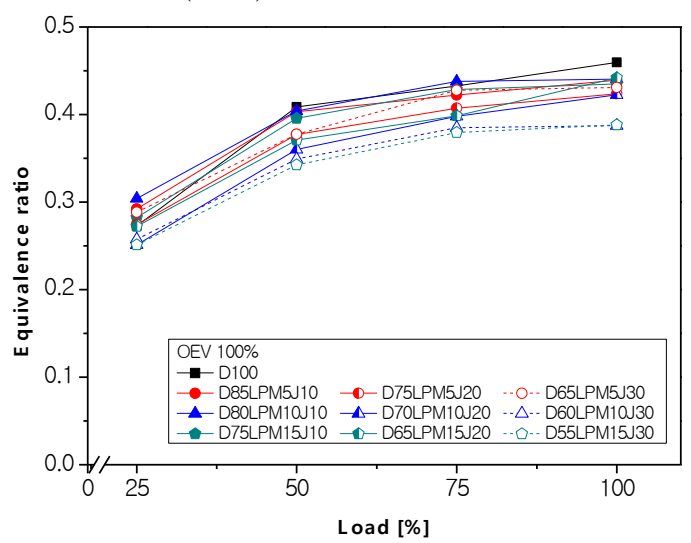

Gambar 16 Pengaruh campuran bahan bakar terhadap equivalence ratio dengan variasi beban menggunakan bukaan katub (OEV) $100 \%$.

Tampak pada Gambar 12 s/d Gambar 16 menunjukkan nilai equivalence ratio meningkat dengan meningkatnya beban. Nilai equivalence ratio menurun ketika menggunakan campuran bahan bakar diesel, metanol kadar rendah dan jatropha. Hal ini disebabkan metanol kadar rendah dan jatropha mem- 
punyai $(\mathrm{AFR})_{\text {stoic }}$ lebih rendah dibandingkan dengan diesel murni, serta metanol kadar rendah memiliki konsentrasi $\mathrm{O}_{2}$ yang tinggi mengakibatkan miskin akan bahan bakar [Zhu et all., 2010]. Nilai equivalence ratio meningkat dikarenakan densitas jatropha yang lebih tinggi menyebabkan lebih banyak bahan bakar yang dilepaskan pompa injeksi untuk satu gerakan piston yang sama [Chauhan et all, 2012]. Tingginya konsumsi bahan bakar, maka aliran masa bahan bakar campuran menjadi meningkat mengakibatkan nilai $(\mathrm{F} / \mathrm{A})_{\text {actual }}$ meningkat, sehingga meningkatkan nilai equivalence ratio.

Gambar 12 menunjukkan pengaruh campuran bahan bakar terhadap equivalence ratio dengan katub (OEV) $0 \%$ cenderung turun. Nilai equivalence ratio tertinggi terjadi pada bahan bakar D100. Penurunan nilai equivalence ratio pada campuran bahan bakar D65LPM15J20 dibanding D100 pada beban $100 \%$ sebesar $12.7 \%$. Begitupun dengan katub (OEV) 25\%. Ketika menggunakan campuran bahan bakar, nilai equivalence ratio meningkat. Nilai equivalence ratio tertinggi terjadi pada bahan bakar D100. Penurunan nilai equivalence ratio pada campuran bahan bakar D80LPM10J10 dibanding D100 pada beban 100\% sebesar $15.71 \%$. Kenaikan nilai equivalence ratio pada campuran bahan bakar D65LPM15J20 pada beban $25 \%$ sebesar $4.52 \%$. Sama juga Gambar 14 menunjukkan pengaruh campuran bahan bakar terhadap equivalence ratio dengan katub (OEV) $50 \%$ cenderung turun. Nilai equivalence ratio tertinggi terjadi pada bahan bakar D100. Penurunan nilai equivalence ratio pada campuran bahan bakar D55LPM15J30 dibanding D100 pada beban $100 \%$ sebesar 15\%. Kenaikan nilai equivalence ratio pada campuran bahan bakar D80LPM10J10 pada beban 25\% sebesar $11.4 \%$.

Sama halnya Gambar 15 menunjukkan pengaruh campuran bahan bakar terhadap equivalence ratio dengan katub (OEV) $75 \%$ cenderung turun. Nilai equivalence ratio tertinggi terjadi pada bahan bakar D100. Penurunan nilai equivalence ratio pada campuran bahan bakar D55LPM15J30 dibanding D100 pada beban 100\% sebesar $15.33 \%$. Kenaikan nilai equivalence ratio pada campuran bahan bakar D70LPM10J20 pada beban 25\% sebesar $9.07 \%$, dan juga Gambar 16 menunjukkan pengaruh campuran bahan bakar terhadap equivalence ratio dengan katub (OEV) $100 \%$ cenderung turun. Nilai equivalence ratio tertinggi terjadi pada bahan bakar D100. Penurunan nilai equivalence ratio pada campuran bahan bakar D55LPM15J30 dibanding D100 pada beban $100 \%$ sebesar $15.54 \%$. Kenaikan nilai equivalence ratio pada campuran bahan bakar D80LPM10J10 pada beban 25\% sebesar $10.23 \%$.

\section{KESIMPULAN}

Meningkatkan nilai equivalence ratio diikuti peningkatan EGR. Nilai equivalence ratio cenderung menurun ketika menggunakan campuran bahan bakar dibandingkan D100. Ada beberapa campuran bahan bakar terjadi peningkatan nilai equivalence ratio dibandingkan D100 untuk D65LPM15J20 dan D80LPM10J10 pada beban rendah (25\%) sebesar $4.52 \%$ dan $11.4 \%$.

\section{DAFTAR NOTASI/ISTILAH}

\begin{tabular}{|c|c|}
\hline SINGKATAN & Nama \\
\hline $\mathrm{A} / \mathrm{F}$ & Air Fuel Ratio \\
\hline $\mathrm{CO}$ & Carbonmonoksida \\
\hline D85LPM5J10 & Diesel $85 \%$ LPM $5 \%$ Jatropha $10 \%$ \\
\hline D80LPM10J10 & Diesel $80 \%$ LPM $10 \%$ Jatropha $10 \%$ \\
\hline D75LPM15J10 & Diesel $75 \%$ LPM 15\% Jatropha $10 \%$ \\
\hline D75LPM5J20 & Diesel $75 \%$ LPM 5\% Jatropha $20 \%$ \\
\hline D70LPM10J20 & Diesel $70 \%$ LPM 10\% Jatropha $20 \%$ \\
\hline D75LPM15J20 & Diesel $75 \%$ LPM $15 \%$ Jatropha $20 \%$ \\
\hline D65LPM5J30 & Diesel $65 \%$ LPM 5\% Jatropha $30 \%$ \\
\hline D60LPM10J30 & Diesel $60 \%$ LPM 10\% Jatropha $30 \%$ \\
\hline D55LPM15J30 & Diesel $55 \%$ LPM 15\% Jatropha $30 \%$ \\
\hline EGR & Exhaust Gas Recirculation \\
\hline $\mathbf{F} / \mathbf{R}$ & Fuel Aür Ratio \\
\hline $\mathbf{H C}$ & Hydrocarbon \\
\hline LPM & Low Purity Metanol \\
\hline OEV & Opening EGR Valve \\
\hline PM & Particular Matter \\
\hline rpm & radius per minute \\
\hline
\end{tabular}

\begin{tabular}{cll} 
LAMBANG & \multicolumn{1}{c}{ Nama } & \multicolumn{1}{c}{ Satuan } \\
$\dot{m}$ & Laju aliran massa & {$\left[\mathrm{kg} \mathrm{s}^{-1}\right]$} \\
$\mathbf{N}$ & Putaran mesin & {$[\mathrm{rpm}]$} \\
$\Phi$ & Rasio ekuivalensi & {$[-]$}
\end{tabular}

\section{DAFTAR PUSTAKA}

Agarwal D, Singh S.K, Agarwal A.K, 2011, "Effect of Exaust Gas Recirculation (EGR) on performance, deposits and durability of constant speed com- 
pression ignition engine, " Elsevier, 88, pp. 2900-2907.

Asif Faiz, Walsh Michael P, Weaver Christopher S,"Air Pollution From Motor Vehicles, Standards and Technologies for Controlling Emissions", The World Bank Washington, D.C, USA, 1996.

Cenk Sayin, Ahmet Necati, Mustafa Canakci, "The Influence of operating parameters on the performance and emissions of a DI diesel engine using metanol-blended-diesel fuel", International Journal of Fuel, Number 89, ScienceDirect, 2009.

Chauhan B.S, Kumar N, Muk H, 2012, "A study on the performance and emission of a diesel engine fueled with jatropha biodiesel oil and its blends," Elsevier, 37, pp. 616-622.

Heywood, John B.L, 1988, "Internal Combustion Engine Fundamentals", McGraw-Hill, Inc, United States of America.
Lei Zhu, C.S. Cheung, W.G. Zhang, Zhen Huang,"Emissions characteristic of a diesel engine operating on biodiesel and biodiesel blended with ethanol and metanol", International Journal of the Total Enviroment, Number 408, ScienceDirect, 2010.

Senthil Kumar, A. Ramesh, B. Nagalingham, 2003, "An Experimental Comparison of Methods to Use Metanol and Jatropha Oil in a Compression Ignition Engine", Department of Mechanical Engineering, Indian Institute of Technology Madras, Chennai, India.

Vinod Singh Yadav, "Perfomance and emission studies of direct injection C.I. engine in duel fuel mode (hydrogendiesel) with EGR", International Journal of Hydrogen energy, Number 37, ScienceDirect, 2012.

Zhiqiang Guo, Tianrui Li, "Combustion and emission characteristic of blends of diesel fuel and metanol to diesel", International Journal of Fuel, Number 90, ScienceDirect, 2011. 